\title{
Needs, expectations and care production of people in street situation
}

\author{
Necessidades, produção do cuidado e expectativas de pessoas em situação de rua \\ Necesidades, producción del cuidado y expectativas de personas en situación de calle
}

\section{Deíse Moura de Oliveira', Adélia Contiliano Expedito', Milleny Tosatti Aleixo', Nicoli Souza Carneiro', Maria Cristina Pinto de Jesus", Miriam Aparecida Barbosa Merighi"l

\author{
' Universidade Federal de Viçosa. Viçosa, Minas Gerais, Brazil. \\ " Universidade Federal de Juiz de Fora. Juiz de Fora, Minas Gerais, Brazil. \\ I"' Universidade de São Paulo, School of Nursing. São Paulo, São Paulo, Brazil.
}

\section{How to cite this article:}

Oliveira DM, Expedito AC, Aleixo MT, Carneiro NS, Jesus MCP, Merighi MAB. Needs, expectations and care production of people in street situation. Rev Bras Enferm [Internet]. 2018;71(Suppl 6):2689-97. [Thematic Issue: Good practices in the care process as the centrality of the Nursing] DOI: http://dx.doi.org/10.1590/0034-7167-2017-0612

\section{Submission: 09-05-2017_Approval: 01-24-2018}

\begin{abstract}
Objective: To understand the needs, expectations, and care production of people in street situations. Method: This is a qualitative study based on social phenomenology, conducted with eight people in street situations. Data were collected through a phenomenological interview from September to December, 2016. Results: The needs of participants refer to survival and access to health services. Care production involves physico-biological, spiritual, and affective-social aspects. The expectations of these people involve a desire for health care that considers their singularities and offers them social apparatuses. Final considerations: This study has contributions to the practice, training on health, and nursing in collective health, regarding care planning and provision to the population in street situations based on their expectations and lifestyles, considered as tools to help fulfill the health needs of this social group.
\end{abstract}

Descriptors: Social Inequity; People in Street Situations; Nursing in Public Health; Culturally Competent Health Care; Qualitative Study.

\section{RESUMO}

Objetivo: compreender as necessidades, as expectativas e a produção do cuidado da população em situação de rua. Método: estudo qualitativo com fundamentação da fenomenologia social, realizado com oito pessoas em situação de rua. Os dados foram coletados por meio de entrevista fenomenológica, de setembro a dezembro de 2016. Resultados: as necessidades dos participantes são de sobrevivência e de acesso aos serviços de saúde. A produção do cuidado envolve aspectos físico-biológicos, espirituais e afetivosociais. As expectativas dessas pessoas expressam o desejo de uma assistência à saúde que considere suas singularidades e lhes ofereça aparatos sociais. Considerações finais: este estudo traz contribuições para a prática, o ensino da saúde e a Enfermagem em Saúde Coletiva quanto ao planejamento e provisão do cuidado à população em situação de rua, a partir de suas expectativas e modos de vida, considerados ferramentas para viabilizar respostas às necessidades em saúde desse grupo social.

Descritores: Iniquidade Social; Pessoas em Situação de Rua; Enfermagem em Saúde Pública; Assistência à Saúde Culturalmente Competente; Pesquisa Qualitativa.

\section{RESUMEN}

Objetivo: Comprender las necesidades, las expectativas y la producción del cuidado de la población en situación de calle. Método: Estudio cualitativo fundamentado en la fenomenología social, realizado con ocho personas en situación de calle. Datos recolectados mediante entrevista fenomenológica, de setiembre a diciembre de 2016. Resultados: Las necesidades de los participantes son de supervivencia y acceso a servicios de salud. La producción de cuidado involucra aspectos físico-biológicos, espirituales y afectivosociales. Las expectativas de estas personas expresan el deseo de una atención de salud que considere sus circunstancias y les ofrezca instituciones sociales. Consideraciones finales: Este estudio pretende contribuir a la práctica, la enseñanza en salud y la Enfermería en Salud Colectiva en la planificación y provisión de atención a la población en situación de cale, a partir de sus expectativas y modo de vida, considerados herramientas para brindar respuestas a las necesidades sanitarias de ese grupo social. 
Descriptores: Inequidad Social; Personas en Situación de Calle; Enfermería en Salud Pública; Asistencia Sanitaria Culturalmente Competente; Investigación Cualitativa.

\section{CORRESPONDING AUTHOR Deíse Moura de Oliveira E-mail: dmouradeoliveira@gmail.com}

\section{INTRODUCTION}

Homelessness is a social phenomenon that shows a public health issue as a result of social inequalities present in many developed, developing, and underdeveloped countries ${ }^{(1)}$.

According to the Annual Homeless Assessment Report (AHAR) to Congress, data published in 2016 by the US Department of Housing and Urban Development showed that, in January 2016, 549,928 people were living in street conditions in that country. Of note, the number of sheltered persons fell by 5\% from 2015 to 2016 and the number of homeless people increased by $2 \%$ in the same period ${ }^{(2)}$, which indicates that the issue of people in street condition in the United States is alarming and growing exponentially.

Brazil is also affected by this problem. In 2008, a National Survey on the Population in a Street Situation was conducted in the country, with the participation of 71 Brazilian municipalities. The results showed 31,922 adults in this situation ${ }^{(3)}$. In 2016, the Institute for Applied Economic Research (Ipea) estimated that there were approximately 101,854 people living in this situation in Brazil(4). These data reinforce the magnitude of this problem of people in street situations in Brazil.

The street context is characterized by singular experiences, usually related to family disruptions and behaviors resulting from abusive use of psychoactive substances (alcohol and other drugs), loneliness, fear, emotional, physical and sexual violence, maltreatment, exposure to crime, financial exploitation, and unemployment or unsuccessful migration in search of better opportunities for survival(5).

As a result, people who live in this reality are daily submitted to violence, due to the circumstances of vulnerability to which they are exposed. They are commonly deprived of basic social rights, such as housing, health care, education, leisure, employment, and safety, among others, which reinforces social inequities in health ${ }^{(6)}$.

In Brazil, the National Policy for the Population in Street Situations, created in 2009 ${ }^{(7)}$, and Directive 122, of January $25,2011^{(8)}$, were important advances to provide this group with access to the basic rights of citizenship through public policies and intersectoral programs. Since then, such advances have attempted to improve the ability to fulfill the health-related demands and needs of the population in street situations ${ }^{(7-8)}$.

Despite the existence of a national public policy for this social group, with legal provisions that guarantee the rights of people in street situations, it is actually not seen in practice, requiring actions by managers and professionals from the social and health areas to increase the visibility of this population. Such visibility should take into account the physical and social vulnerability of the street population, with special attention to equitable care, and understanding the needs of this group in order to help the health and social care system fulfill them ${ }^{(9)}$.

The literature shows that this social group has received care mainly through actions involving hygiene or support, strongly influenced by the fundamental perspective of public health ${ }^{(9)}$.
It is a challenge for the field of collective health which, by considering street people as subjects, and not objects, of health practices, sees them as care producers in their daily life, instead of receivers of interventions of care from professionals.

Care production refers to ethical ways people in street situation use to conduct themselves in their daily lives as networks of existences, in contrast to other different forms of logic of existence that are imposed on them by institutions ${ }^{(10)}$. This concept of needs rooted in imaginary and professional practices is based on the understanding that such needs are exclusively related to privation, determined from the external/objective to the internal/subjective environment. Therefore, they are considered as resulting only from the judgment of the professional, whereas in fact they are social and historical processes defined by the agents involved ${ }^{(11)}$.

Considering the expanded concept of health that is understood as a social phenomenon, whose production is permeated by the context in which individuals and collectivities live, assisting people in street situations represents a challenge to health professionals as a whole ${ }^{(12)}$. Nursing is inserted into this context as a social practice that seeks to understand and meet the needs of people at individual and collective levels and promote the potentialities and dignity of people as social individuals ${ }^{(13)}$.

Due to the lack of information in the literature about the needs, expectations, and care production from the perspective of people in street conditions, the following questions guided this study: What are the needs of people in street conditions? Based on these needs, how do these people produce care in their daily life on the street? Considering the care production performed and the needs perceived by this population, what kind of care do these people expect to be offered?

\section{OBJECTIVE}

To understand the needs, expectations, and care production of the population in street situations.

\section{METHOD}

\section{Ethical aspects}

This study fulfilled the ethical requirements contained in Resolution 466/2012 of the National Health Council, with a favorable opinion from the Human Research Ethics Committee of the Federal University of Viçosa.

\section{Theoretical-methodological framework and type of study}

This was a qualitative study based on Alfred Schütz's theoretical perspective on social phenomenology, whose principle is to interpret the meaning of the actions of subjects in the social world. It is based on theoretical assumptions that help us to understand social actions that use the theory of human motivation, understood from "reasons why" and "reasons for." The first refer to the 
life context of homeless people, which places them in a given biographical situation according to the knowledge/experience they have. "Reasons for" consider this context as predictive for the person to build expectations that will constitute the flow of social action/experience in the social world. The meaning of the action lies in the intersubjective relation that will produce a sense common to the experiences lived by a certain social group ${ }^{(14)}$.

\section{Study scenario and participants}

The study scenario was the central area of a municipality of Minas Gerais, Brazil, of estimated 77,863 inhabitants ${ }^{(15)}$. In terms of the Unified Health System (SUS), this municipality does not have a street doctor program. Regarding the Unified Social Service System (SUAS), the municipality offers a specialized social service center (CREAS) that provides care to the population in street situations through the Special High Complexity Social Protection Sector Coordination. In this context, the municipality has a social service (Casa de Passagem) that for a specific period receives individuals in compromised situations such as people in street situations.

The inclusion criteria were: people declaring they were in a street situation and over 18 years of age, regardless of gender.

\section{Source of data}

This study used a convenience sample, selecting participants via snowball sampling. In this technique, the first participant is chosen for convenience, and this participant recruits the second, who in turn will recruit the third participant, and so on. The effectiveness of this method has been recognized especially when minority groups are studied, as observed in this study ${ }^{(16)}$.

\section{Data collection and organization}

Data collection was conducted from September to December 2016 by a professor (research advisor) and three students from the nursing program, scientific initiation scholarship holders with experience in qualitative studies.

To allow the first contact with the population in a street situation, a face-to-face meeting was arranged with the social worker of the Municipal Department of Social Service of the study municipality, who has worked with this population for about 20 years. He was asked to provide the study team with information about one person in a street situation and the place where this person is usually found in the city. Then the researchers started the exploratory visits to the study scenario. The researchers, after mapping potential participants, visited the urban areas where they were to start a contact with this population at different times before receiving their statements.

A phenomenological interview ${ }^{(17)}$ was used to collect data from the following questions: What are your needs, considering the fact of living on the street? How do you take care of yourself in your daily life on the street? What could be done to improve care for you, considering the fact that you live on the street? For participant characterization, information was obtained about the reasons that led them to live on the street and how long they had been in this situation, in addition to gender, age, occupation, and region where they live. When the interview was conducted, only the researcher and the participant were present.
Before giving the interviews, the participants received explanations about the study objectives and the importance of their participation in the study. The Informed Consent Form (ICF) was read by the researchers and signed by the participants. For data collection, the study team contacted 11 people who met the inclusion criteria, with two denied participation. The statement provided by one participant whose content was unrelated to the study theme was eliminated, so eight interviews with people in a street situation were included in the study analysis.

The number of participants was not further increased when the content of the interviews was enough to fulfill the study objective, allowing the researchers to reach the depth, comprehensiveness, and complexity involved in understanding the studied theme ${ }^{(18)}$.

The interviews were conducted individually, at moments when the people in the street situation were available and open to provide their testimonials. Considering the need for privacy and minimum noise, the participants were asked to indicate urban spaces that would fulfill such specific need of qualitative studies. The statements were audio-recorded and lasted approximately 60 minutes each. To preserve anonymity, the participants were identified with "I" (interviewee) followed by the number corresponding to the order in which the interviews were conducted (I1 to I8).

\section{Data analysis}

The organization, categorization, and analysis of the material obtained $^{(17)}$ were conducted by the team of researchers. After reading each statement in full, the health needs of the people in street situations and their ways to produce and consider care within the social reality in which they live were identified. For organization of the material, convergence of meanings related to the studied phenomenon was performed to create concrete categories, defined as objective constructs developed by the researcher, based on the experience explained by the participants ${ }^{(14)}$. The discussion of the results was based on the assumptions of Alfred Schütz's social phenomenology and thematic reference.

\section{RESULTS}

\section{Participant characterization}

This study had eight participants, seven male and one female, aged from 34 to 71 years, with time in a street situation from eight months to 25 years. Seven participants lived in the central region and one in the peripheral region of the city, which is covered by the Family Health Strategy. Their reason for living on the streets was predominantly use of alcohol and other drugs (generators of family conflicts). Regarding the activities performed on the street, the only female participant in the study is retired and claims that she does not ask money on the street. Four men have informal jobs, specifically as garbage collectors; one receives a family allowance from the government; two are exclusively beggars; and one is retired.

\section{Thematic categories resulting from the study}

\section{Needs of people in a street situation}

According to the participants, the needs of people in street situations include those related to safety, food, sleep, and rest; a place for their physiological needs; and access to health 
services. Regarding safety, the testimonies emphasize it as a permanent need in this social reality:

[...] they hurt us very much, throw stones, hit us [...] Sleeping on the street is too bad, they can burn us [...] I sleep in the middle of the street, running the risk of dying. (I3)

[...] I'm afraid to stay on the street [...] I'm afraid to die and not to see my grandchildren grow up ... I owe drug money, I already had a gun pointed at my head by a drug dealer while I was at the bus station. (I8)

The challenge to find food and a proper place to sleep, rest, and provide for physiological needs was highlighted by the participants:

We starve, we go through a lot of things [...] there's no place to sleep. (14)

[...] If I think better, I guess I sleep and get up with my eyes open, wide open. Sometimes I have a nightmare [...]. Then I feel scared and wake up feeling nervous. [...] in one moment I'm sleeping, in another I feel afflicted, I'm afraid, I wake up. (I7)

My problem [...] is that I'm kind of embarrassed when I want to use the toilet [...] and ask people to let me go to the toilet. (I7)

The need for access to health services, aggravated by the absence of a healthcare program for people in street situations and an ID document program, was also reported:

Those who live on the street have no treatment; they do not like to treat us. [...] there are people who may be not eating, who are lying on the street almost dead, but they don't care; a health car passes and doesn't pick these people up. (I1)

[...] we go see a doctor and they ask for a card that we don't have [...] we are miserable because we live on the street and have no documents [...] we just survive. For hospital admission, they ask for our ID document, voter's document, everything. (16)

\section{Care production by people in street situations}

Care production in daily life on the street occurs through support networks created by the people in street situations themselves. These networks are configured to meet physicobiological, spiritual, and affective-social needs.

Regarding the physico-biological aspect, the strategies developed to provide bodily care, food, and shelter are highlighted:

[...] I can wash my clothes at the gas station [...] I know everyone there [...] I can use the tank on the bottom [...]. I've slept there too for many years now [...]. When it's cold and raining, I seek another place, because the place I sleep is open; if it rains, I get wet [...]. I have covers, I have clothes, I leave everything there, at the gas station. (I2)

I know everyone [...]. People from the young group, I have contact with them [...]. I ask things from them and they help me. If I want to eat something, they go and buy something for me. (E5)

I take a shower at the St. Vincent de Paul shelter [...]. I go to every home asking for food. (I8)

In the studied context, people in street situations define therapeutic behaviors for themselves according to their perspective of their own health conditions:

[...] I threw the medicine away because I read in the insert what I was feeling [...]. It gives eczema, I was having eczema again on the leg, look at my feet how black they are [...]! [...] Look there, it is dry [shows feet with a dry appearance]. (I1)

The spiritual aspect is an important reference of care for these people, who seek in it the support for their life on the street:

God takes care of me. I pray God for a better life [...] for my life to get better. (I4)

[...] that's me and God, only Him, no one helps me more than He [...]. He gives me strength, makes me better when I'm feeling bad. [...] I feel bad and I'm alone where I live. (I5)

The network of care created on the street is also expressed in the affective and social field, as seen in the following statements:

[...] when I die, I will be missed [...] I have many friends. Many people help me. I'm very friendly, I like to talk. If I leave here, everyone will be looking for me. (I1)

I have people who support me, people who help me [...] People who are with us. (I3)

Within this social network, care production is established to protect the documents belonging to persons in street situations, who are under the custody of others of their trust:

[...] for not losing on the street, I leave my documents with a friend [...]. He has a flower shop [...] my ID, labor record booklet, I leave with him [...] if I stay on the street, I'm going to drink, I'm going to lose them, I'm going to fall [...] I prefer to leave them there, and I only have a copy of them with me. (I2)

[...] I have all documents [...] I leave them with a friend. (I7)

The statement of one participant shows that occupation also appears as one way of care production in their daily life:

[...] I take care of myself, and I depend very much on the bus station, to carry people's bags [...] no one is going to give me a bag to carry if I am very drunk and very dirty [...] otherwise I lose [my] space. (I2)

\section{Expectations of care of people in street situation}

Based on the care they need and the context where they live, people in street situations show expectations that, according to them, can help them have a better quality of life in their reality. 
The expectations of care in this social group are expressed by the desire for social apparatuses such as a shelter to meet their needs for safety, food, sleep and rest, and hygiene, as well as health care that considers their singularities:

[...] if you break an arm, they [the health professionals] are going to bandage and do it their own way [...] there should be somebody in charge to take care of us after I leave the hospital [...]. They should have people to look after the people on the street. (I1)

[...] I think there should be a shelter here, like the ones you have in other cities, a place that, when [you] arrive at night, show your document, then you go inside [...] take a shower, have dinner, and sleep, and then you leave in the morning. (I2)

This city doesn't even have a shelter for us to sleep! You have to sleep in the square. Oh, God! I want to find a shelter and get off the street! [...] I wish I could go home! I wish. (I3)

Another desire raised by people in street situations was also related to the network of care for this population referring to the provision of treatment for those who use alcohol and other drugs:

I needed a clinic to be hospitalized. Health means you stop drinking and start living [...] just because of that [lack of help to stop drinking] then I can't do it. (I3)

I wanted to go to a rehabilitation clinic that would heal, get [me] off drugs, and then [I could] take care of my children. [...] but I have no support, my family doesn't support me. (14)

\section{DISCUSSION}

By analyzing the reality of people in street situations, this study focused on critically discussing and analyzing the aspects involved in the relation between what these people need, the care they produce, and what they expect to achieve, a triad that is considered the flow of the social action/experience of this study.

This flow takes place in the social world, in which the meanings of human action emerge from the social relations the person develops, thus located in a intersubjective world, where human beings act based on the knowledge they have, which is culturally constituted through their experiences in the scope of micro and macro social macrostructure. It leads the person to a biographical situation ${ }^{(14)}$ which, in this study, refers to the context of life on the street.

The "reasons why" of people in street situations derive from their past and present experiences ${ }^{(14)}$, among which are their needs. The concept of needs is fundamental in health work, including nursing. They are unique in that they differ depending on the place the person occupies in the world. In addition, they express the conditions of vulnerability and are closely related to it; therefore, it is critical to capture them from the subjectivity of individuals and social groups ${ }^{(19)}$.

Health is said to depend on fulfilling the needs related to survival (food, shelter, safety) and social processes (protection; affection; understanding; identity; freedom; and access to health, education, and leisure). The latter are related to self-realization and are based on equality and mutual recognition of the human condition in the social context ${ }^{(20)}$.

From this perspective, it is evident that the participants in this study, when asked about their needs in the street context, related their needs to health. For analysis purposes, these will be conceived of in this study as health needs, which implies an ongoing dialogue with several intersectoral actors, programs, and policies for them to be fulfilled, appearing as a challenge of collective health.

As seen in the present study, living in the public spaces of the city subjects people in this reality to a context characterized by many vulnerabilities, with emphasis on lack of safety. The paradox is that, in the social imagination, there is a predominant concept that it is the people in street situations who create a lack of safety and urban violence toward the society that excludes them ${ }^{(9)}$.

The participants stated that living in a street situation means constantly running the risk of being a victim of violence, a fact confirmed by a study conducted in Maryland, United States, which reported that, in a period from 2003 to 2011, 279 people in street situation were victims of violent death ${ }^{(21)}$. In Brazil, a study with 251 individuals in street situations in São Paulo showed that $65 \%$ reported lack of safety on the streets and $45.7 \%$ said they had suffered aggression in the prior month ${ }^{(22)}$.

The literature also shows that people in this situation find it difficult to obtain food, a proper place to sleep, rest, and meet their physiological needs ${ }^{(9)}$, confirming the results of this study. In this context, a study conducted in Rhode Island, United States, with 319 homeless adults, showed that more than $94 \%$ of the participants presented food insecurity, and $64 \%$ of this subgroup had already experienced starvation ${ }^{(23)}$.

Sleeping on the street is a complex task that can affect health. A study with 244 adults in street situations in Dallas, Texas (US) reported inadequate sleep, with fewer hours of rest and greater involuntary sleep in this group when compared to the general population that has a home. This is an aspect that influences the health/disease process of these individuals, resulting in cognitive and mood disorders and poor health self-assessment ${ }^{(24)}$.

Regarding physiological needs, in the absence of a home, the people who live on the streets use public spaces and toilets of commercial establishments (such as from bars and bakeries). It usually happens in establishments whose owners are known to these people, so that this link acts as an enabler to meet this need $^{(25)}$, a reality also found in this study.

Another need that emerged from the statements of participants refers to the access to health services, either due to the absence of healthcare programs and services for this population or lack of access due to the absence of an ID document, commonly observed in the population in a street situation. From this perspective, a network of health care structured to meet the needs of this population is very important, with the street doctor program considered a milestone that has brought advances to the organization of care to this social group.

The study municipality does not offer a street doctor program. The National Policy on Primary Care establishes that, in municipalities where this program does not exist, integral care to these individuals is the responsibility of basic care $(A B)^{(26)}$. 
However, because a substantial portion of this population lived in the central regions of the city, places where $A B$ is not usually prioritized, the studied social group did not receive care from the health services.

The literature indicates that difficulty in accessing health services, as a consequence of the lack of ID documents, is a reality experienced by this population ${ }^{(1,9,27)}$. This practice is unconstitutional considering that equity, integration, and universality of care are guaranteed by the SUS, which as a health system should provide social responses to the needs of the population in street situations ${ }^{(1)}$. Frustrated attempts at receiving care end up causing these people to generally seek help only in emergency situations ${ }^{(1)}$. A study conducted in Canada showed that people in street situations presented high rates of acute health care, including visits to the emergency department and hospital admission, and this pattern is seen in countries with and without universal health systems ${ }^{(28)}$.

Based on the needs perceived by these social subjects, internal networks are created in the street context, anchored by intersubjective relations permeated by bonds and affection, thus configuring an anchoring dimension of care production in this social reality. The participants in this study explained this intersubjectivity in their experiences as the core of the way to organize themselves to produce care on the streets. This showed the social action ${ }^{(14)}$ of these individuals, which allowed them to transform/reconfigure themselves on a daily basis from the intersubjective relations they build in the social reality where they live.

The literature reports that, in their connections, people constitute networks of existence, because within their lifeworld they produce care, building knowledge. This should be considered in the process of health care production, because life strategies, experiences, and lifestyle say a lot about who these individuals are and what they really need ${ }^{(10)}$.

The networks of existence created by the participants in the intersubjective relations of this study are producers of care to meet the needs of a physico-biological, spiritual, and affective-social character. The search for charitable organizations, churches, and commercial establishments such as restaurants and gas stations, shows the networks they have formed to meet their needs related to food, rest, and body hygiene. This fact is in agreement with a study conducted in Brazilian capitals with adults in street situations ${ }^{(5,22,25)}$.

Intersubjective processes, in addition to promoting social cohesion, provide a transcendence of experiences not related to the concrete. Such transcendence finds in religious experience one way to express the individual's social action in their lifeworld ${ }^{(14)}$. In this context, the production of care on the street is also based on spirituality. The interviewees rely on faith to overcome the challenges faced in the street reality, mostly seeking God's support, a result in agreement with that of another study conducted in Brazil(29).

In addition, the networks created by affections in the daily life on the street allow these individuals to protect their belongings and build friendly relationships that meet their affective-social needs. From this perspective, one interviewee highlighted the reception received from health professionals of basic care, a peculiar situation found in the study, because this was the only one that lives in a space of the family health strategy program. According to the literature, living on the street means gradually building a new daily life, supported by the public space with its residents and users. Consequently, relationships are established all the time and are essential for day-to-day construction, both in people's lives and in social groups ${ }^{(25)}$.

In this context, the informal job activity of the participants acts as a tool that enables care-because it results in the subsistence of the individual-and depends on it, because the interviewees themselves report that it is necessary to take care of their physical appearance to avoid losing their work. In addition, it is an element that enables social inclusion and health promotion for this vulnerable population ${ }^{(30)}$.

The networks created on the streets, despite allowing participants to meet their needs, showed incomplete fulfillment of these needs, given the complexity seen in the care provided to people in street situations. In this context, expectations of care emerge from this social group.

Such expectations refer to the "reasons for" of the social action in question that emerge from the biographical situation and the collection of knowledge/experiences in their social reality $^{(14)}$. Thus the needs revealed by the studied social group are related to survival and human needs, considered the "reasons why" of the social action analyzed, culminating in projections to meet those needs, considered the "reasons for" of the social action in question.

Participants want a better quality of life in the reality where they live, considering a shelter as a social apparatus that can meet their needs of home, safety, food, sleep, and rest, a result also found in other studies conducted in Brazil in both midsize $\mathrm{e}^{(31)}$ and large ${ }^{(25)}$ cities.

Regarding the expectations related to fulfillment of human needs-access to health services, self-realization, and understanding, among others ${ }^{(20)}$ - the study group expressed a desire to have professional support in the street reality. Their wish to keep receiving care after going to health institutions in the street context presupposes the expansion of $\mathrm{AB}$ coverage in the central regions of the city ${ }^{(26)}$, the implementation of programs such as the street doctor program ${ }^{(9)}$, and/or specific arrangements of healthcare networks focused on the singularities of this group.

Freedom, considered by the study group as the wish to get rid of the habit of taking alcohol and other drugs, was reported by the participants. The abusive use of psychoactive substances remains and is aggravated by the experiences on the streets ${ }^{(5)}$, leading to an interruption in this link through admission to rehabilitation clinics, a wish of many people in street situations to restore their family life. However, the literature states that the admission of people in street situations can be considered ineffective, especially when it occurs involuntarily ${ }^{(32)}$, given the complexity involved in recovering from psychoactive substance abuse.

The National Survey on Populations in Street Situations in Brazil identified that, of 31,922 adults, $35.5 \%$ were in this situation due to alcoholism and other drugs ${ }^{(3)}$. In this sense, it is important to consider the role of the family, which should work together with healthcare professionals to strengthen the 
treatment and reintegration of these people after they are discharged from the clinic back to their family context ${ }^{(33)}$.

The "reasons for" explained by the participants in this study showed the completeness of the social action/experience established in the intersubjective networks produced from the reality in which they are inserted, strengthening the assumption of Alfred Schütz's social phenomenology: that intersubjectivity is an essential element in the social construction of the senses.

\section{Study limitations}

Understanding the needs, expectations, and care production based on the studied reality shows the peculiar characteristics of the experience of being a person in a street situation, which can differ if the same aspects are investigated in different contexts, such as in large urban centers. Therefore, this study does not propose generalization, but rather presents perspectives of a complex reality inherent to the social phenomenon studied in this investigation.

\section{Contributions to health, public policies, and nursing}

By showing the subjectivities and intersubjectivities involved in care from the perspective of street people, this study shows the real health needs of the studied social group. Such subjectivities and intersubjectivities should be considered by policymakers for the promotion of equity in health and other special policies for this population in order to enforce the Unified Health System principles among this group, which is historically deprived of the right to health. Giving visibility to this portion of society will enable its health needs to be fulfilled through the organizational arrangements of healthcare networks and new ways of organizing the health/work process, which is a challenge for collective health.
From this perspective, this study expects to contribute to the practice and, when teaching health and nursing in collective health, regarding the planning and provision of care to the population in street situations, based on their expectations and lifestyles, considered tools to help fulfill the health needs of this social group.

This may lead to resignification of care to people living in this situation, instituting it as a social action based on equity and integrality, as well as a political act that enables social transformation and justice.

\section{FINAL CONSIDERATIONS}

This study analyzed the needs, expectations, and care production of people in street situations. It showed that these needs are related to human survival and access to health services. Care production occurs in the physico-biological, spiritual, and affective-social fields, and the expectations of the participants were expressed in their need for social apparatuses and wish for health care that considers their singularities.

The findings of this study should be combined with others from qualitative studies involving the population in street situations in order to offer references to managers of public policies, especially social ones. For nursing, conceived as a profession whose object of practice is care, the results of this study should be used to (de)construct and (re)build itself based on the singular care expressed in the perspectives of the street population.

This move, strengthened in the scope of management and followed by synergistic actions in the field of service, teaching, and research broadening the dialogue about the population in street situations, forces collective health care to find effective, intersectoral, and humanized solutions to reduce social inequities in health generated around this population.

\section{REFERENCES}

1. Paiva IKS, Lira CDG, Justino JMR, Miranda MGO, Saraiva AKM. Homeless people's right to health: reflections on the problems and components. Ciênc Saúde Colet[Internet]. 2016[cited 2017 Jun 13];21(8):2595-606. Available from: http://www.scielo.br/pdf/ csc/v21n8/en_1413-8123-csc-21-08-2595.pdf

2. Henry M, Watt R, Rosenthal L, Shivji A. Annual Homeless Assessment Report to (AHAR) Congress[Internet]. US: HUD. Office of Community Planning and Development. 2016[cited 2017 Jun 22]. Available from: https://www.hudexchange.info/resources/ documents/2016-AHAR-Part-1.pdf

3. Brasil. Ministério do Desenvolvimento Social e de Combate à Fome. Rua, aprendendo a contar: pesquisa nacional sobre a população em situação de rua[Internet]. 2009[cited 2017 Jun 14]. Available from: http://www.mds.gov.br/webarquivos/publicacao/ assistencia_social/Livros/Rua_aprendendo_a_contar.pdf

4. Brasil. Ministério do Planejamento. Instituto de Pesquisa Econômica Aplicada. Estimativa da População em Situação de Rua no Brasil[Internet]. 2016[cited 2017 Jun 14]. Available from: http://www.ipea.gov.br/portal/images/stories/PDFs/TDs/26102016td_2246.pdf

5. Donoso MTV, Bastos MAR, Faria CRD, Costa AA. Ethnographic study on homeless people in a big urban center. Rev Min Enferm[Internet]. 2013[cited 2017 Jun 13];17(4):902-9. Available from: www.reme.org.br/exportar-pdf/894/v17n4a11.pdf

6. Sotero M. Vulnerability and vulneration: street population, an ethical issue. Rev Bioét[Internet]. 2011[cited 2017 Jun 13];19(3):799817. Available from: http://revistabioetica.cfm.org.br/index.php/revista_bioetica/article/view/677/727

7. Brasil. Decreto Presidencial No 7.053, de 23 de dezembro de 2009: institui a Política Nacional para a População em Situação de Rua e seu Comitê Intersetorial de Acompanhamento e Monitoramento, e dá outras providências. Diário Oficial da União 24 de dezembro de 2009[Internet]. 2009[cited 2017 Jun 14]. Available from: http://www.planalto.gov.br/ccivil_03/_ato2007-2010/2009/ decreto/d7053.html

8. Brasil. Portaria № 122, de 25 de janeiro de 2011: define as diretrizes de organização e funcionamento das Equipes de Consultório 
na Rua. Diário Oficial da União, 26 de janeiro de 2012[Internet]. 2009[cited 2017 Dec 28]. Available from: http://189.28.128.100/ dab/docs/legislacao/portaria_122_25_01_2011.pdf

9. Hallais JAS, Barros NF. Consultório na Rua: visibilidades, invisibilidades e hipervisibilidade. Cad Saúde Pública[Internet]. 2015[cited 2017 Jun 14];31(7). Available from: http://www.scielo.br/pdf/csp/v31n7/0102-311X-csp-31-7-1497.pdf

10. Merhy EE, Gomes MPC, Silva E, Santos MFL, Cruz KT, Franco TB. Redes Vivas: multiplicidades girando as existências, sinais da rua. Implicações para a produção do cuidado e a produção do conhecimento em saúde. Divulg Saúde Debate[Internet]. 2014[cited 2017 Jun 20];52:153-64. Available from: http://www.gov.scot/Publications/2017/06/8907/downloads

11. Merhy EE. O cuidado é um acontecimento e não um ato. In: Franco TB, Merhy EE. Trabalho, produção do cuidado e subjetividade em saúde. São Paulo: Hucitec; 2013. p. 172-82.

12. Regis CG, Batista NA. The nurse in the area of collective health: conceptions and competencies. Rev Bras Enferm[Internet]. 2015[cited 2017 Jun 14];68(5):548-54. Available from: http://www.scielo.br/pdf/reben/v68n5/en_0034-7167-reben-68-05-0830.pdf

13. Zoboli ELCP, Schveitzer MC. Nursing values as social practice: a qualitative meta-synthesis. Rev Latino-Am Enfermagem[Internet]. 2013[cited 2017 Jun 14];21(3):695-703. Available from: http://www.scielo.br/pdf/rlae/v21n3/0104-1169-rlae-21-03-0695.pdf

14. Schütz A. Sobre fenomenologia e relações sociais. Petrópolis: Vozes; 2012.

15. Brasil. Instituto Brasileiro de Geografia e Estatística-IBGE. Cidades: Viçosa. Estimativa populacional, 2016[Internet]. 2016[cited 2017 Jul 14]. Available from: http://www.cidades.ibge.gov.br/xtras/perfil.php?lang = \&codmun =317130

16. Cohen L, Arieli T. Field research in conflict environments: methodological challenges and snowball sampling. J Peace Res[Internet]. 2011[cited 2017 Jun 14];48(4):423-35. Available from: http://journals.sagepub.com/doi/pdf/10.1177/0022343311405698

17. Jesus MCP, Capalbo C, Merighi MAB, Oliveira DM, Tocantins FR, Rodrigues BMRD, et al. The social phenomenology of Alfred Schütz and its contribution for the nursing. Rev Esc Enferm USP[Internet]. 2013[cited Jul 15 2017];47(3):736-41. Available from: http://www.scielo.br/pdf/reeusp/v47n3/en_0080-6234-reeusp-47-3-00736.pdf

18. Minayo MCS. Amostragem e saturação em pesquisa qualitativa: consensos e controvérsias. RPQ[Internet]. 2017 [cited Jul 13 2017];5(7):1-12. Available from: http:// http://rpq.revista.sepq.org.br/index.php/rpq/article/view/82/59

19. Nakamura E, Egry EY, Campos CMS, Nichiata LYI, Chiesa AM, Takahashi RF. The potential of an instrument to identify social vulnerabilities and health needs: collective health knowledge and practices. Rev Latino-Am Enfermagem[Internet]. 2009 [cited 2017 Jul 13];17(2):253-8. Available from: http://www.scielo.br/pdf/rlae/v17n2/pt_18.pdf

20. Oliveira MAC. Re(thinking) nursing curative projects through the light of population health needs. Rev Bras Enferm[Internet]. 2012[cited 2017 Jul 13];65(3):401-5. Available from: http://www.scielo.br/pdf/reben/v65n3/v65n3a02.pdf

21. Stanley JL, Jansson AV, Akinyemi AA, Mitchell CS. Characteristics of violent deaths among homeless people in Maryland, 20032011. Am J Prev Med[Internet]. 2016[cited 2017 Jun 14];51(5):260-6. Available from: http://www.sciencedirect.com/science/ article/pii/S0749379716303117

22. Barata RB, Carneiro JN, Ribeiro MCSA, Silveira C. Health social inequality of the homeless in the city of São Paulo. Saúde Soc[Internet]. 2015[cited 2017 Jun 14];24(1):215-27. Available from: http://www.scielo.br/pdf/sausoc/v24s1/en_0104-1290-sausoc-24-s1-00219.pdf

23. Martins DC, Gorman KS, Miller RJ, Murphy L, Sor S, Martins JC, et al. Assessment of food intake, obesity, and health risk among the homeless in Rhode Island. Public Health Nurs[Internet]. 2015[cited 2017 Jun 14];32(5):453-61. Available from: http://onlinelibrary. wiley.com/doi/10.1111/phn.12180/epdf

24. Chang HL, Fisher FD, Reitzel LR, Kendzor DE, Nguyen MA, Businelle MS. Subjective sleep inadequacy and self-rated health among homeless adults. Am J Health Behav[Internet]. 2015[cited 2017 Jun 20];39(1):14-21. Available From: http://www.ingentaconnect. com/content/png/ajhb/2015/00000039/00000001/art00002

25. Andrade LP, Costa SL, Marquetti FC. The street has a magnet, I think it is freedom: power, suffering, and life strategies among homeless persons in the City of Santos, São Paulo, Brazil. Saúde Soc[Internet]. 2014[cited 2017 Jun 14];23(4):1248-61. Available from: http://www.scielo.br/pdf/sausoc/v23n4/0104-1290-sausoc-23-4-1248.pdf

26. Brasil. Ministério da Saúde. Secretaria de Atenção à Saúde. Departamento de Atenção Básica. Política Nacional de Atenção Básica[Internet]. 2012[cited 2017 Jun 13]. Available from: http://189.28.128.100/dab/docs/publicacoes/geral/pnab.pdf

27. Toledo L, Góngora A, Bastos FIPM. À margem: uso de crack, desvio, criminalização e exclusão social: uma revisão narrativa. Ciênc Saúde Colet[Internet]. 2017[cited 2017 Jun 14];22(1):31-42. Available from: http://www.scielo.br/pdf/csc/v22n1/1413-8123csc-22-01-0031.pdf

28. Fazel S, Geddes JR, Kushel M. The health of homeless people in high-income countries: descriptive epidemiology, health consequences, and clinical and policy recommendations. Lancet[Internet]. 2014[cited 2017 Jun 15];384(9953):1529-40. Available from: https://www.ncbi.nlm.nih.gov/pmc/articles/PMC4520328/

29. Santos SMR, Jesus MCP, Mattos LR, Alves MJM, Vicente EJD, Jesus PBR. Spirituality in assessing the quality of life of the collectors of recyclable materials: cross sectional study. O Braz J Nurs[Internet]. 2012[cited 2017 Jul 16];11(1):1-11. Available from: http:// www.objnursing.uff.br/index.php/nursing/article/view/3661

30. Henrique RA, Santos CM, Vianna JJB. Sentidos e significados do trabalho entre pessoas em situação de rua. Psicol Am Lat[Internet]. 2013[cited 2017 Jun 20];24:109-20. Available from: http://pepsic.bvsalud.org/pdf/psilat/n24/a08.pdf 
31. Biscotto PR, Jesus MCP, Silva MH, Oliveira DM, Merighi MAB. Understanding of the life experience of homeless women. Rev Esc Enferm USP[Internet]. 2016[cited 2017 Jul 15];50(5):749-55. Available from: http://www.scielo.br/pdf/reeusp/v50n5/0080-6234reeusp-50-05-0750.pdf

32. Coelho I, Oliveira MHB. Internação compulsória e crack: um desserviço à saúde pública. Saúde Debate[Internet]. 2014 [cited 2017 Dec 05];38(101):359-67. Available from: http://www.scielo.br/pdf/sdeb/v38n101/0103-1104-sdeb-38-101-0359.pdf

33. Caravaca-Morera JA, Padilha MI. The family relationships dynamics of homeless people-crack users. Saúde Debate[Internet]. 2015[cited 2017 Jun 20];39(106):748-59. Available from: http://www.scielo.br/pdf/sdeb/v39n106/0103-1104-sdeb-39-106-00748.pdf 